\title{
PENGEMBANGAN MEDIA KOMIK IPA MODEL INKUIRI TERBIMBING UNTUK MENINGKATKAN ASPEK KOGNITIF PESERTA DIDIK SMP
}

\author{
Nursina Sari' ${ }^{1}$ A. K. Prodjosantoso ${ }^{2}$ \\ Dosen, Universitas Muhammadiyah Mataram; Guru Besar, Universitas Negeri Yogyakarta² \\ Nursinasari1234@gmail.com, prodjosantoso@yahoo.com
}

\begin{abstract}
INFO ARTIKEL
Riwayat Artikel:

Diterima: $23-11-2017$

Disetujui: 10 - 12 - 2017
\end{abstract}

\section{Kata Kunci: \\ 1. Komik IPA \\ 2. Inkuiri terbimbing \\ 3. Aspek kognitif}

\begin{abstract}
ABSTRAK
Abstrak Penelitian ini bertujuan untuk mengetahui: (1) kelayakan dan (2) keefektifan komik hasil pengembangan dalam peningkatan aspek kognitif peserta didk setelah menggunakan media komik hasil pengembangan model guided inquiry di dalam pembelajaran IPA. Penelitian ini adalah penelitian dan pengembangan yang mengadaptasi model dari Borg \& Gall. Pengujian terbatas menggunakan desain eksperimen one group pretest-posttest dan pengujian operasional menggunakan desain kuasi eksperimen nonequivalent pretest-posttest control group design. Hasil penelitian menunjukkan bahwa media komik IPA: (1) layak digunakan dengan kriteria "sangat baik", dan (2) efektif meningkatkan aspek kognitif peserta didik secara signifikan, dengan nilai alpha sebesar 0,031 .
\end{abstract}

\section{A. LATAR BELAKANG}

Pendidikan merupakan hal penting sehingga menjadi suatu langkah utama oleh pemerintah yang harus dilakukan dalam menyiapkan warga negaranya untuk mampu bersaing dan mempertahankan hidupnya di persaingan global. Lahirnya kurikulum 2013 sebagai upaya penyempurnaan kurikulum sebelumnya adalah salah satu langkah pemerintah untuk meningkatkan kualitas pendidikan. Pendidikan tidak hanya berorientasi pada kecerdasan manusia semata, namun juga pada aspek keagamaan, pengendalian diri, kepribadian, kecerdasan, akhlak mulia, serta ketrampilan yang diperlukan dirinya, masyarakat, bangsa, dan Negara.

Kurikulum 2013 mengisyaratkan agar pembelajaran tidak berorientasi pada hasil melainkan pada proses. Ilmu Pengetahuan Alam sebagai salah satu mata pelajaran di SMP/MTs yang diatur dalam kurikulum 2013 adalah sebagai proses meliputi kecenderungan sikap atau tindakan, keingintahuan, kebiasaan berpikir, dan seperangkat prosedur yaitu pendekatan ilmiah. Dengan begitu penyampaian pembelajaran sains atau Ilmu Pengetahuan Alam setidaknya memperhatikan pembentukan pengetahuan dalam benak peserta didik. Bloom (Anderson \& Krathwohl, 2010: pp.105-114), pemahaman didefinisikan sebagai kemampuan untuk menyerap arti dari materi atau bahan yang dipelajari. Peserta didik dikatakan memahami ketika mereka mampu menghubungkan pengetahuan baru dan pengetahuan lama yang mereka peroleh dalam proses penyelesaiann suatu permasalahan. Suparno (2001, pp.142-143) menyatakan bahwa anak dalam perkembangannya mempunyai struktur pemikiran yang berbeda dengan orang dewasa. Peserta didik sendirilah yang harus mengartikan apa yang telah diajarkan oleh guru dan belajar menyesuaikan terhadap pengalamanpengalaman yang diperoleh melalui kegiatan berpikir dan kecenderungan dalam bersikap di kehidupan sehari-hari. Dalam hal ini kegiatan memahami merupakan bagian dari proses kognitif. Proses kognitif dalam memahami meliputi menafsirkan, mencontohkan, mengklasifikasikan, merangkum, menyimpulkan, membandingkan, dan menjelaskan.

Submateri kalor khususnya perpindahan kalor merupakan materi yang berada dalam kehidupan seharihari. Selain karena pada materi ini tercakup karakteristik IPA, materi kalor sangat dekat dengan kehidupan seharihari sehingga materi kalor dapat diintegrasikan dengan materi lainnya. Selain itu juga karena indikator pencapaian kompetensinya adalah sesuai dengan pembelajaran berbasis penemuan, yaitu menyelidiki peran kalor dalam merubah wujud benda. Peserta didik dalam hal proses pencarian konsep tersebut tentunya dapat menggunakan pendekatan ilmiah yaitu model inkuiri terbimbing yang sesuai dengan pembelajaran IPA. Model inkuiri terbimbing merupakan suatu proses berpikir yang ditempuh oleh peserta didik yang diawali dengan proses pengajuan pertanyaan yang kemudian menerapkan pengetahuan yang 
ada melalui kegiatan eksperimen. Materi ini cocok jika dikembangkan dengan menggunakan alur cerita sebagai penghubung antara submateri yang satunya dengan submateri lainnya.

Pembelajaran IPA hakikatnya tidak lepas dari bahan ajar dan media yang digunakan. Selaras dengan perkembangan teknologi dan informasi saat ini, proses pembelajaran membutuhkan suatu pengembangan dalam menyampaikan suatu pesan kepada peserta didik. Akan tetapi, kenyataan di lapangan belum sesuai dengan harapan pemerintah kaitannya dengan pembelajaran yang mengarahkan pada pengembangan ranah pengetahuan, sikap dan keterampilan. Sudjana \& Rivai (2011, pp.1-2) menyatakan bahwa bahan pembelajaran merupakan seperangkat materi keilmuan yang terdiri atas fakta, konsep, prinsip, generalisasi suatu ilmu yang bersumber dari kurikulum dan dapat menunjang tercapainya tujuan pembelajaran, sedangkan media pembelajaran merupakan alat bantu mengajar yang dapat mempertinggi proses belajar peserta didik melalui pencarian konsep dan pada akhirnya dapat mempertinggi hasil belajar yang dicapainya.

Penggunaan media tidak dilihat dari segi kecanggihannya, tetapi yang lebih penting adalah fungsi dan peranannya dalam membantu proses pembelajaran dan membantu mempertinggi proses pengajaran (Sudjana dan Rivai, 2010, p.4). Tella (Norsalisa et al., 2013, p.15) menyatakan tanpa dukungan media pembelajaran, kegiatan belajar mengajar yang hanya menggunakan buku pelajaran sebagai satu-satunya sumber belajar oleh peserta didik, menjadikan suasana belajar menjadi kurang menarik dan membosankan serta membuat anak kurang mengembangkan kemampuan serta kreativitas peserta didik, dengan begitu peserta didik malas belajar dan menilai bahwa belajar IPA sulit, sehingga berkurangnya minat peserta didik terhadap pembelajaran IPA.

Minat merupakan modal awal terbentuknya motivasi. Ketika minat peserta didik berkurang, maka motivasi peserta didik untuk belajar IPA juga berkurang. Ketika peserta didik kurang tertarik terhadap pelajaran maka akan mempengaruhi cara mereka bereaksi atau memperhatikan guru. Salah satu upaya dalam meningkatkan minat belajar peserta didik yaitu penggunaan media pembelajaran yang menarik. Salah satu media pembelajaran yang dapat membantu peserta didik memberikan gambaran-gambaran dari materi pada buku teks adalah media pembelajaran visual seperti komik.

Waluyanto (Widyawati, 2015, p.25) menyatakan media komik merupakan bentuk media komunikasi visual yang mempunyai kekuatan untuk menyampaikan informasi secara popular dan lebih mudah dimengerti karena terdiri dari gambar dan tulisan yang dirangkai dalam alur cerita, sehingga mudah dipahami. Pemberian pengalaman belajar yang menyenangkan dapat meningkatkan hasil belajar peserta didik. Selain itu, penggunaan komik sains dalam pembelajaran membuat kegiatan pembelajaran lebih menarik dan tidak membosankan menjadikan minat belajar peserta didik menjadi lebih tinggi. Penggunaan komik ini lebih ditekankan pada proses pembelajaran yang meliputi seluruh kegiatan pembelajaran sebagai alur pembimbing kegiatan pembelajaran dan penyedia materi pelajaran sehingga mengarahkan peserta didik dalam menerapkan pengetahuan dengan cara menyelesaikan suatu jenis kegiatan yang sudah dirancang dalam lembar kerja peserta didik sehingga aspek kognitif dalam pembelajaran sains dapat ditingkatkan.

Berdasarkan pembahasan yang diuraikan, perlu dilakukan penelitian pengembangan media pembelajaran IPA komik tema kalor di sekitar kita dengan model guided inquiry untuk meningkatkan aspek pengetahuan peserta didik SMP.

Tujuan penelitian ini untuk: (1) Mengetahui kelayakan media komik IPA dan (2) Mengetahui perbedaan antara penerapan pembelajaran menggunakan media komik IPA tema kalor ditinjau dari aspek kognitif peserta didik SMP kelas VII.

\section{B. METODE PENELITIAN}

Jenis penelitian ini adalah penelitian dan pengembangan atau Research and Development (R\&D). Penelitian ini dilakukan melalui pendekatan quasi experiment dengan jenis nonequivalent control group pretest-posttest design. Prosedur pengembangan yang diakukan dalam penelitian ini meliputi 9 tahapan yang di tunjukkan oleh Gambar 1.

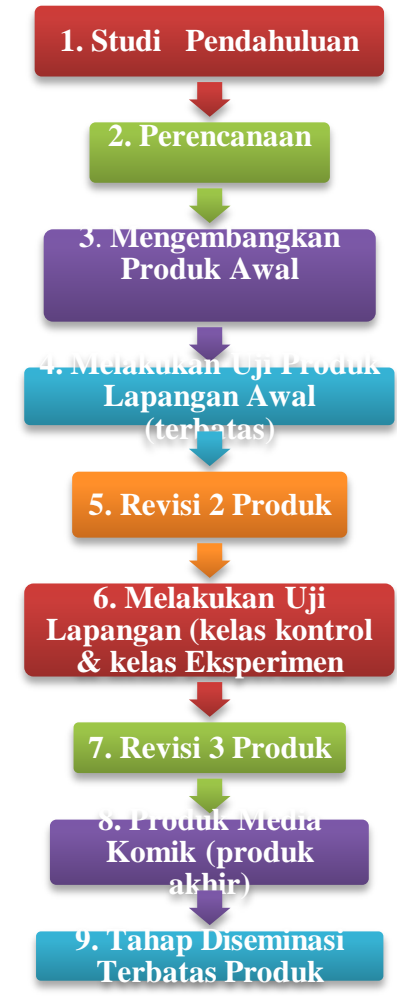

Gambar 1. Langkah Pengembangan Produk 
Jenis data pada penelitian ini berupa data kualitatif data kuantitatif. Data kualitatif diperoleh dari hasil tanggapan ahli materi dan ahli media, dan peserta didik melalui angket, dan wawancara, yang berisikan masukan, tanggapan dan saran yang nantinya akan dianalisis. Hasil analisis ini akan digunakan untuk melakukan perbaikan atau merevisi media komik sains yang dikembangkan. Data kuantitatif yang berupa skor berdasarkan pencapaian indikator pada setiap sub aspek, dimana setiap sub aspek masing-masing terdiri dari 5 indikator melalui observasi, hasil validasi ahli dan penilaian guru IPA serta teman sejawat, uji coba lapangan awal (terbatas), dan uji coba lapangan (kelas kontrol dan kelas eksperimen).

Produk dikatakan layak digunakan jika memiliki kriteria minimal baik. Data hasil penilaian untuk media IPA berupa skor yang diperoleh berdasarkan pencapaian indikator pada setiap sub aspek. Skor dari masing-masing penilai dijumlahkan, kemudian dirata-rata. Skor penilaian diubah menjadi nilai dalam skala 100 dengan persamaan:

Nilai Akhir $=\frac{\text { Skor yang diperoleh }}{\text { Skor maksimum }} \times 100$

Produk dikatakan layak digunakan jika memiliki kriteria minimal "baik". Konversi skor menjadi nilai mengacu pada persamaan berikut, dimana konversi kriteria penilaian media dapat dilihat pada Tabel 1.

Tabel 1.

Kriteria Penilaian Media

\begin{tabular}{|c|c|c|c|}
\hline \multicolumn{2}{|c|}{ Interval Skor } & Nilai & Kategori \\
\hline Rumus & Perhitungan & & \\
\hline $\begin{array}{l}\mathrm{X}>\mathrm{Xi}+ \\
1,8 \mathrm{Sbi}\end{array}$ & $X>4$ & A & $\begin{array}{c}\text { Sangat } \\
\text { baik }\end{array}$ \\
\hline $\begin{array}{c}\mathrm{Xi}+0,6 \mathrm{SBi}< \\
\mathrm{X} \leq \mathrm{Xi}+1,8 \\
\mathrm{SBi}\end{array}$ & $3<X \leq 4$ & B & Baik \\
\hline $\begin{array}{c}\mathrm{Xi}-0,6 \mathrm{SBi}< \\
\mathrm{X} \leq \mathrm{Xi}+0,6 \\
\mathrm{SBi}\end{array}$ & $2<X \leq 3$ & $\mathrm{C}$ & $\begin{array}{l}\text { Cukup } \\
\text { baik }\end{array}$ \\
\hline $\begin{array}{c}\mathrm{Xi}-1,8 \mathrm{SBi}< \\
\mathrm{X} \leq \mathrm{Xi}-0,6 \\
\mathrm{SBi}\end{array}$ & $1<X \leq 2$ & $\mathrm{D}$ & $\begin{array}{l}\text { Kurang } \\
\text { baik }\end{array}$ \\
\hline $\begin{array}{c}\mathrm{X} \leq \mathrm{Xi}-1,8 \\
\text { Sbi }\end{array}$ & $X \leq 1$ & $\mathrm{E}$ & $\begin{array}{c}\text { Sangat } \\
\text { kurang } \\
\text { baik }\end{array}$ \\
\hline
\end{tabular}

Keterangan:

Skor maksimal $=5$

Skor minimal $=0$

$\mathrm{Xi}=$ rerata

$=1 / 2($ skor maksimal + skor minimal $)$

$=1 / 2(5+0)$

$=2,5$
Sbi= simpangan baku ideal

$=1 / 6$ (skor maksimal - skor minimal)

$=1 / 6(5-0)$ $=0,833$

Hasil belajar aspek kognitif peserta didik yaitu melalui tes tertulis berupa soal pilihan ganda dan soal uraian. Besarnya peningkatan kemampuan kognitif dianalisis dengan meggunakan nilai Gain. Nilai awal (pretest) dan nilai akhir (postest) digunakan untuk memeroleh Gain score melalui persamaan yang dikemukakan oleh Bao (2006: 917) :

$\mathrm{g}=\frac{(\text { posttest score })-(\text { pretest score })}{\text { maximum possible score }-(\text { pretest score })}$

Nilai gain kemudian diklasifikasikan dengan kriteria gain skor, kriteria gain score menurut Hake (1991: 1) disajikan pada Tabel 2.

Tabel 2.

Kriteria Gain Skor

\begin{tabular}{ll}
\hline \multicolumn{1}{c}{ Kriteria } & \multicolumn{1}{c}{ Nilai } \\
\hline Tinggi & $\mathrm{g} \geq 0,7$ \\
Sedang & $0,7>\mathrm{g} \geq 0,3$ \\
Rendah & $\mathrm{g}<0,3$ \\
\hline
\end{tabular}

Analisis data dilakukan dengan menggunakan uji statistik, yaitu uji-t dengan tujuan untuk mengetahui signifikansi signifikansi beda rata-rata kemampuan aspek kognitif pada kelas kontrol dan eksperimen yang menggunakan media pembelajaran IPA komik dan tidak menggunakan media pembelajaran IPA komik. Persyaratan uji t yang harus terpenuhi jika data tersebar normal dan homogen. Uji statistik normalitas data yaitu dengan Kolmogrof-Smirnov. Data dikatakan terdistribusi normal jika p-value lebih besar dari 0,05.

\section{HASIL DAN PEMBAHASAN}

Hasil penelitian ini berupa produk media pembelajaran IPA komik. Pada pengembangan produk, tahap yang perlu dilakukan adalah validasi dan penilaian produk. Validasi produk terbagi atas ahli materi, ahli media. Validator ahli materi adalah dosen FMIPA yang menguasai materi IPA dan validator ahli media adalah dosen FBS Seni Rupa yang menguasai ilustrasi dan komik. Hasil penilaian dari validator ahli materi dan media yaitu berupa skor, masukan, dan saran untuk pengembangan komik melalui tahap revisi. Komik setelah direvisi kemudian dianjutkan dengan penilaian oleh guru IPA SMP dan teman sejawat yang terdiri dari 2 guru IPA dan 2 teman sejawat mahasiswa Pascasarjana jurusan pendidikan IPA. Hasil penilaian dari penilaian produk yaitu berupa skor, masukan, dan saran yang dapat digunakan untuk melakukan revisi terhadap produk. 
Adapun hasil validasi produk oleh ahli materi menujukkan bahwa draf awal pengembangan media pembelajaran berbentuk komik memiliki kriteria sangat baik yaitu dengan rata-rata sebesar 4,29. Kemudian hasil validasi produk oleh ahli media menujukkan bahwa draf awal pengembangan media pembelajaran berbentuk komik memiliki kriteria sangat baik yaitu dengan rata-rata sebesar 4,78 .

Adapun hasil penilaian oleh guru IPA (1) dan teman sejawat (1) sebagai penilai kelompok pertama diperoleh hasil bahwa media pembelajaran berbentuk komik yang dikembangkan masuk ke dalam kriteria sangat baik dengan nilai penskoran yaitu 4,75 untuk guru IPA (1) dan 4,81 untuk teman sejawat (1). Berikut disajikan skor rata-rata hasil penilaian kelompok kedua oleh guru IPA (2) dan teman sejawat (2) media pembelajaran berbentuk komik pada seluruh sub aspek dalam Gambar 1.

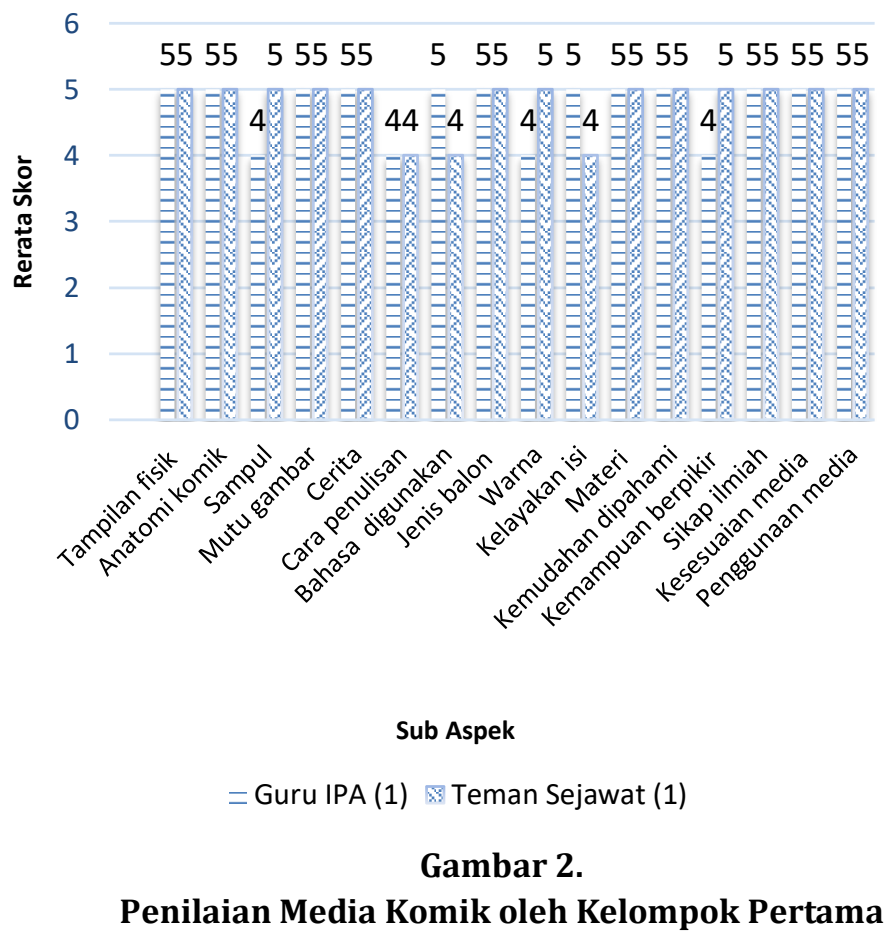

Pada persentase kesepakatan (percent of agreement) antar penilai pada kelompok pertama diperoleh hasil perhitungan koofisien kesepakatan penilaian terhadap komik pada seluruh sub aspek yaitu 0,96 atau 96,25\% yang tergolong reliabel atau baik.

Sementara hasil penilaian oleh guru IPA (2) dan teman sejawat (2) sebagai penilai kelompok kedua diperoleh hasil bahwa media pembelajaran berbentuk komik yang dikembangkan masuk ke dalam kriteria sangat baik dengan nilai penskoran yaitu 4,75 untuk guru IPA (2) dan 4,81 untuk teman sejawat (2). Berikut disajikan skor rata-rata hasil penilaian kelompok kedua oleh guru IPA (2) dan teman sejawat (2) media pembelajaran berbentuk komik pada seluruh sub aspek dalam Gambar 2.
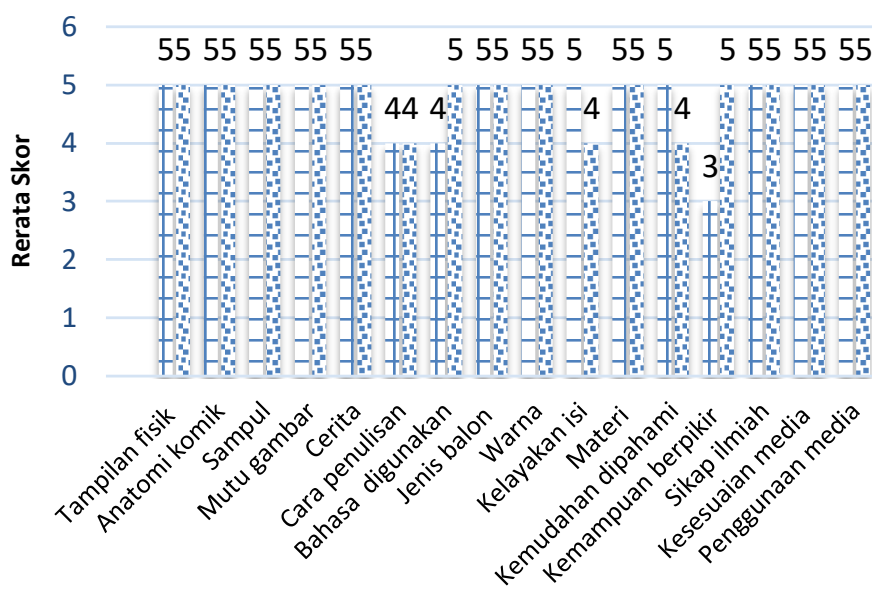

Sub Aspek

- Guru IPA (2) Teman Sejawat (2)

\section{Gambar 3.}

Penilaian Media Komik oleh Kelompok Kedua

Pada persentase kesepakatan (percent of agreement) antar penilai pada kelompok kedua diperoleh hasil hasil perhitungan koofisien kesepakatan penilaian terhadap komik pada seluruh sub aspek yaitu 0,96 atau 96,25 \% yang tergolong reliabel atau baik.

Baik penilaian oleh ahli, guru IPA maupun teman sejawat menunjukkan bahwa media pembelajaran IPA komik pada seluruh sub aspek baik. Dari keseluruhan hasil-hasil tersebut menunjukkan bahwa media pembelajaran IPA komik yang dkembangkan masuk dalam kriteria sangat baik, sehingga layak dan valid unuk digunakan dalam pembelajaran.

Peningkatan hasil kemampuan aspek kognitif dapat dilihat dengan membandingkan nilai pretest dan posttest baik pada kelas eksperimen maupun pada kelas kontrol. Peningkatan hasil kemampuan aspek kognitif peserta didik diperoleh dengan cara mencari Gain Score. Data rerata Gain Score untuk kemampuan aspek kognitif antara kelas eksperimen dan kelas kontrol selengkapnya pada Tabel 3.

Tabel 3.

Rerata Gain Kemampuan Aspek Kognitif

\begin{tabular}{lccc}
\hline \multicolumn{1}{c}{ Aspek } & Pretest & Posttest & Gain \\
\hline Kelas Eksperimen & 41,38 & 81,17 & 0,68 \\
Kelas Kontrol & 41,17 & 77,14 & 0,61 \\
\hline
\end{tabular}

Perbandingan rerata Gain Score untuk kemampuan aspek kognitif antara kelas eksperimen dan kelas kontrol terangkum disajikan pada Gambar 4. 


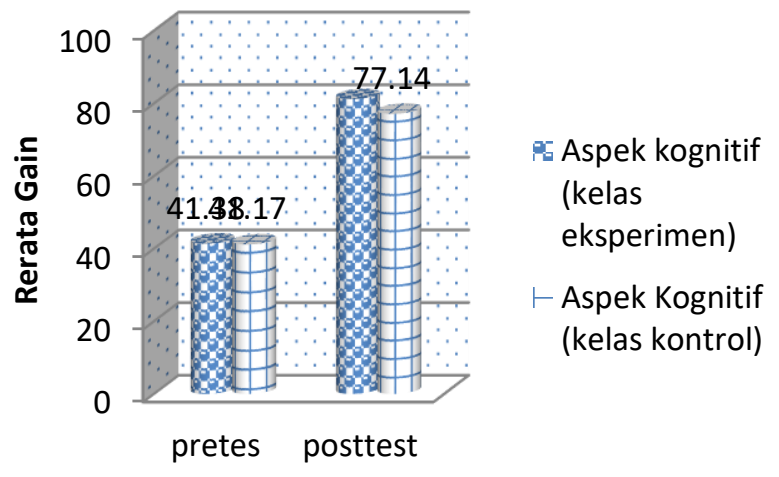

Hasil Uji Rerata Gain Aspek Kognitif

\section{Gambar 4.}

\section{Histogram Hasil Uji Rerata Gain Aspek kognitif}

Hasil yang diperoleh menunjukkan bahwa kemampuan aspek kognitif peserta didik kelas eksperimen sebelum proses pembelajaran mendapatkan skor 41,38 dan setelah mendapat perlakuan 81,17 dengan peningkatan gain 0,68 berkategori sedang. Pada kelas kontrol sebelum mendapat perlakuan proses pembelajaran mendapatkan skor 41,17 dan setelah mendapat perlakuan 77,14 dengan peningkatan gain 0,61 berkategori rendah.

Berdasarkan perolehan nilai gain dapat disimpulkan bahwa media pembelajaran IPA komik dapat meningkatkan kemampuan aspek kognitif peserta didik. Hal tersebut didukung oleh penelitian tentang pembuatan komik sains inkuiri oleh Nugraha (2013) yang menunjukkan peningkatan hasil belajar kognitif peserta didik berdasarkan uji gain.

Ada tidaknya perbedaan hasil kemampuan aspek kognitif menggunakan media pembelajaran IPA komik dilakukan dengan menggunakan uji statistik uji-t, dapat dihasilkan output yang dapat dilihat selengkapnya pada Tabel 4.

Tabel 4. Uji-t

\begin{tabular}{cc}
\hline $\begin{array}{c}\text { Levene's Test for Equality } \\
\text { of Variances }\end{array}$ & $\begin{array}{c}\text { Asymp. Sig. (2- } \\
\text { tailed) }\end{array}$ \\
\hline 0,358 & 0,031 \\
\hline
\end{tabular}

Berdasarkan hasil analisis data menggunakan SPSS uji normalitas pada taraf signifikansi 5\%, diperoleh nilai signifikasi sebesar 0,2 dan 0,153. Dapat disimpulkan bahwa data tersebut berdistribusi normal, sedangkan uji homogenitas varian nilai signifikansinya 0,358 yang berarti lebih dari $\alpha 0,05$ sehingga dapat disimpulkan bahwa data tersebut homogen. Data aspek kognitif diuji menggunakan Two Independent Sample Test dan didapatkan nilai Sig. (2tailed) sebesar 0,031 dengan kata lain terdapat perbedaan pada kelas eksperimen dan kelas kontrol pada taraf signifikansi 5\%. Hal tersebut sesuai dengan penelitian yang dilakukan oleh Wahyuningsih (Widyawati, 2015: 25) bahwa media pembelajaran dengan menggunakan komik dapat meningkatkan hasil belajar, sehingga mencapai KKM serta dapat meningkatkan minat dan ativitas belajar peserta didik. Hal ini juga didukung oleh penelitian yang dilakukan Puspito Rini (2014) menunjukkan bahwa penggunaan media komik IPA berkarakter dapat meningkatkan hasil belajar peserta didik ranah kognitif (pengetahuan) dengan gain skor sebesar 0,42.

Secara teoritis dan praktis, dari hasil penelitian menunjukkan bahwa penggunaan media pembelajaran IPA komik inkuiri terbimbing lebih efektif dibandingkan pembelajaran tanpa menggunakan media pembelajaran IPA komik. Hal ini juga didukung oleh penelitian yang dilakukan Dewi (2013) menunjukkan bahwa penggunaan setting inkuiri terbimbing dalam perangkat pembelajaran dapat meningkatkan aspek kognitif peserta didik.

\section{SIMPULAN DAN SARAN}

Berdasarkan hasil penelitian yang telah dilakukan, maka dapat disimpulkan sebagai berikut:

1. Berdasarkan penilaian ahli dan pendidik terhadap produk buku petunjuk praktikum IPA terpadu berbasis home materials dapat disimpulkan bahwa produk hasil pengembangan dikategorikan sangat baik sehingga layak untuk digunakan.

2. Terdapat pengaruh yang signifikan antara nilai rata-rata angket motivasi peserta didik yang menggunakan buku petunjuk praktikum berbasis home materials (kelas treatment) dengan yang tanpa menggunakan buku petunjuk praktikum berbasis home materials (kelas kontrol).

\section{DAFTAR RUJUKAN}

[1] Anderson, W.L., \& Krathwohl, R.D. 2010. Kerangka Landasan Untuk Pembelajaran, Pengajaran dan Assessmen. Yogyakarta: Pustaka Pelajar

[2] Dewi, K, Sadia, I. W, \& Ristiati, N. P. 2013. Pengembangan Perangkat Pembelajaran IPA Terpadu Dengan Setting Inkuiri Terbimbing Untuk meningkatkan Pemahaman Konsep dan Kinerja Ilmiah Peserta Didik. E-journal Pascasarjana Universitas Pendidikan Ganesha. Program Studi Pendidikan IPA

[3] Nugraha, E. A, Yulianti, D. \& Khanafiyah, S. 2013. "Pembuatan Bahan Ajar Komik Sains Inkuiri Materi Benda untuk Mengembangkan Karakter Siswa Kelas IV SD". Unnes Physics Education Journal. UPEJ 2, (1), halaman 60-68.

[4] Puspitorini, R. 2014. Pengembangan Media Komik IPA Berkarakter sebagai Implementasi Kurikuum 2013 untuk Meingkatkan Motivasi dan Hasil Belajar Peserta Didik kelas VII. Cakrawala Pendidikan, Oktober 2014, Th. XXXIII, No. 3.

[5] Sudjana, N, \& Rivai, A. 2011. Media Pengajaran. Bandung: Sinar Baru Algensindo. 
Jurnal Elementary | Vol. 1, No. 1, Januari 2018, hal 5-10

[6] Suparno, P. 2001. Teori Perkembangan Kognitif Jean Piaget. Yogyakarta: Kanisius.

[7] Widyawati, A., \& Prodjosantoso, A. 2015. Pengembangan Media Komik IPA untuk Meningkatkan Motivasi Belajar dan Karakter Peserta Didik SMP. Jurnal Inovasi Pendidikan IPA, 1(1), 24-35. Diakses pada tanggal 14 Agustus 2015, diambil dari situs http://journal.uny.ac.id/index.php/iipi/article/view/ $\underline{4529}$. 